\title{
Leaf extracts of Melia azedarach Linnaeus (Sapindales: Meliaceae) act as larvicide against Aedes aegypti (Linnaeus, 1762) (Diptera: Culicidae)
}

\author{
Extratos de folhas de Melia azedarach Linnaeus \\ (Sapindales: Meliaceae) atuam como larvicida de Aedes aegypti \\ (Linnaeus, 1762) (Diptera: Culicidae)
}

\author{
Josiane Somariva Prophiro ${ }^{1,2}$, Juliana Chedid Nogared Rossi², Murilo Fernandes Pedroso², \\ Luiz Alberto Kanis ${ }^{3}$ and Onilda Santos Silva ${ }^{2}$
}

\begin{abstract}
The objective of this study was to compare the larvicidal effect of hydroethanolic extracts of fresh and dry leaves of Melia azedarach Linnaeus (Sapindales: Meliaceae) on Aedes aegyti (Linnaeus, 1762) (Diptera: Culicidae). All the extracts evaluated induced mortality among the third and fourth instar larvae of Aedes aegypti after 24 and 48 hours of exposure to the products. Although previous studies had demonstrated the action of seeds and fruits of Melia azedarach against the larvae of different Aedes aegypti populations, the present report is the first to show the larvicidal effect of the fresh and dry leaves of this plant.
\end{abstract}

Key-words: Aedes aegypti. Melia azedarach. Control. Natural products.

\section{RESUMO}

O objetivo deste trabalho foi comparar o efeito larvicida de extratos hidro-etanólicos de folhas verdes e secas de Melia azedarach Linnaeus (Sapindales: Meliaceae) em Aedes aegypti (Linnaeus, 1762) (Diptera: Culicidae). Todos os extratos avaliados induziram mortalidade em larvas de $3^{\circ}$ e $4^{\circ}$ estágios de Aedes aegypti, após 24 e 48 horas de exposição aos produtos. Embora estudos prévios tenham demonstrado a ação de sementes e frutos de Melia azedarach em larvas de diferentes populações de Aedes aegypti, o presente estudo é o primeiro a reportar o efeito larvicida de folhas verdes e secas desta planta.

Palavras-chaves: Aedes aegypti. Melia azedarach. Controle. Produtos naturais.

Aedes aegypti (Linnaeus, 1762) (Diptera: Culicidae) is the main vector of the dengue virus in Brazil, and the present situation is characterized mainly by widespread vectorial infestation in all regions of the country. Control over this species can be accomplished by elimination or cleaning of the sites that serve as breeding sites for the larvae, through biological control and, especially, using synthetic insecticides. However, constant use of synthetic insecticides induces resistance in populations of Aedes species. In Brazil, resistance of Aedes aegypti to organophosphates has been reported in Brasília ${ }^{3}$, Goiás ${ }^{8}$, São Paulo ${ }^{7}$, Rio de Janeiro and Espírito Santo ${ }^{6}$, Manaus ${ }^{14}$ and other regions of Brazil ${ }^{11}$.
One alternative approach preventing the development of resistance in mosquitoes could be to use products obtained from insecticidal plants. Substances extracted from these plants are obtained from renewable resources, are rapidly degraded and, more importantly, insects exhibit only very slow development of resistance to such substances, which are composed of associations of various active agents ${ }^{16}$.

Some natural insecticides are obtained from leaves, fruits and seeds of certain species of the Meliaceae family. Among these, studies have been carried out on Azadirachta indica Adrien-Henri de Jussieu ${ }^{12}$ and Carapa guianensis Aublet ${ }^{92021}$. On the other hand,

\footnotetext{
1. Laboratório de Entomologia Médica e Veterinária, Universidade Federal do Paraná, Curitiba PR. 2. Laboratório de Entomologia Médica, Universidade do Sul de Santa Catarina, Tubarão SC. 3. Laboratório de Tecnologia Farmacêutica, Universidade do Sul de Santa Catarina, Tubarão SC.

Financial support: CNPq.

Address to: Prof. Onilda Santos da Silva. Av. José Acácio Moreira 787, Dehon, 88704-900 Tubarão, SC.

Tel: 5548 3621-3294; Fax: 5548 3621-3067.

e-mail: onildasilva@yahoo.com.br

Recebido para publicação em 25/04/2008

Aceito em 29/10/2008
} 
great emphasis has been given to the chinaberry Melia azedarach Linnaeus (Sapindales: Meliaceae), popularly known in Brazil as cinamomo. Studies have shown that this plant presents considerable efficacy with regard to controlling agriculturally important insects ${ }^{243}$. In relation to medically important insects, there have been reports of efficacy against the barber bug Triatoma infestans (Klug) ${ }^{24}$ and the mosquitoes Anopheles stephens $i^{13}$, Aedes aegypti ${ }^{1525}$ and Aedes albopictus ${ }^{17}$.

The results have indicated that these two separate botanical parts of the plant show significant larvicidal activity. The use of other botanical parts could contribute towards more efficient use of this plant, in order to develop natural products for controlling this vector species. Thus, the objective of this study was to compare the larvicidal effect of ethanolic extracts between fresh and dry leaves of Melia azedarach on Aedes aegypti.

\section{MATERIAL AND METHODS}

Mosquitoes. Bioassays were carried out using third and fourth instar larvae from a temephos-resistant colony of Aedes aegypti (Zoonosis Control Management; Gerência de Controle de Zoonoses, GCZ), obtained from the National Health Foundation (Fundação Nacional de Saúde), Brasília. This colony had been maintained in the laboratory for six years, at a temperature of $25 \pm 2{ }^{\circ} \mathrm{C}$ and $\mathrm{RH}$ of $75-85 \%$, with a light:dark period of $14: 10$.

Extracts. The leaf samples of Melia azedarach were collected from trees located in the region of Sertão dos Corrêas, Tubarão, Santa Catarina, during 2004 and 2005. The leaves were dried by placing the collected material in a dark and well-ventilated place at room temperature for 15 days. After drying, the leaves were ground to a fine powder in a blender. Hydroethanolic extracts were obtained by adding $300 \mathrm{~g}$ of each material (fresh leaves and dry leaves) to a macerator with 1.9 liters of extraction liquid (ethanol:water 50:50, 70:30 and 100:0) for five days with mechanical stirring. Next, the extracts were filtered and concentrated in a rotary evaporator under vacuum and at a temperature of $40^{\circ} \mathrm{C}$, until the crude extract was obtained.

Bioassays. The concentrations of hydroethanolic extract of fresh and dry leaves of Melia azedarach used in the bioassays ranged from $0.060 \%$ to $1.8 \%(\mathrm{~m} / \mathrm{V})$. The crude extract was previously solubilized in Tween-20 at a concentration of $0.015 \%$ and a temperature of $40^{\circ} \mathrm{C}$. This was then added to a predefined volume of deionized water at $40^{\circ} \mathrm{C}$ and the resulting mixture was stirred for 30 minutes. One hundred $\mathrm{ml}$ of the solutions containing the extract at different concentrations were added to plastic containers of capacity $350 \mathrm{ml}$. Then, 20 active third or fourth instar larvae were transferred to this solution. The tests were repeated at least five times for each concentration and larval stage. For each experiment, a control was used containing water and Tween-20. The mortality among the larvae was measured after 24 and 48 hours of exposure to the solutions. Mortality was confirmed when the larvae did not show any movement in response to being touched with histological needles.

Statistics. The mean mortality data on the third and fourth instar larvae were subjected to probit analysis ${ }^{5}$, to calculate the
$\mathrm{LC}_{50}$ for the 24 and 48 hours of exposure. The Kruskal-Wallis and Wilcoxon-Mann-Whitney tests were used through the Statistica 6.0 software, to analyze differences between the means for larvae mortality. Statistical significance was defined at a level of $\mathrm{P}<0.05 \%$.

\section{RESULTS}

From the bioassays carried out on crude extracts of fresh and dry leaves of Melia azedarach in 50, 70 and 100\% ethanol, the susceptibility levels of the Aedes aegypti larvae expressed as $\mathrm{LC}_{50}$ values are shown in Tables 1 and 2 . The absence of larval mortality in all control groups indicated that Tween-20 did not affect larval development.

Statistical comparisons indicated that there were no significant differences in larval mortality induced by the extracts of fresh and dry leaves, compared according to larval instar, over the 24 and 48 -hour periods of exposure $\left(X^{2}=0.22 ; d f=1 ; P=0.6374\right)$.

On the other hand, there was a significant difference in mortality, for both the third and the fourth instar, between 24 and 48 hours of exposure to the extracts of fresh and dry leaves $\left(X^{2}=8.00 ; d f=1 ; P=0.0047\right)$.

Comparative analysis between larval mortality and ethanolic concentration (50, 70 and $100 \%)$ of the fresh and dry leaf extracts over the 24 and 48-hour periods showed some differences. There were significant differences between $50 \%$ and $70 \%$ ethanol $(P=0.00198)$ and between $50 \%$ and $100 \%$ ethanol $(P=0.00036)$. However, there was no significant difference between the 70 and $100 \%$ ethanol concentrations $(P=0.4270)$.

Comparison of the $\mathrm{LC}_{50}$ for the extracts of fresh and dry leaves after 48 hours of exposure was very interesting: all of the leaf extracts (fresh and dry) of Melia azedarach analyzed induced mortality among the third and fourth instar larvae of Aedes aegypti. However, a higher level of mortality was observed using 100\% ethanol concentration (Figure 1).

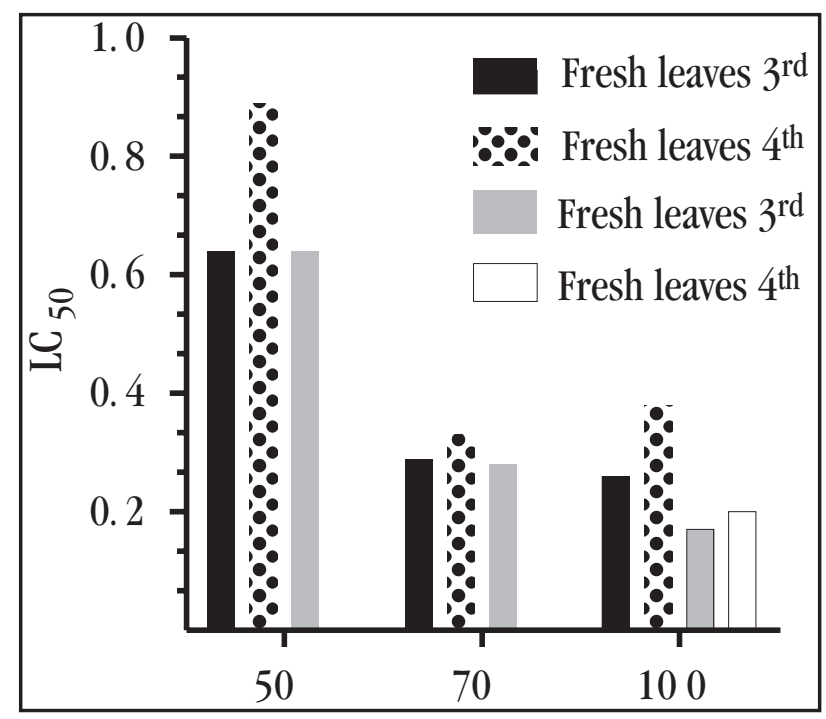

Figure 1 - Comparison of lethal concentrations $\left(L C_{50}\right)$ of hydroethanolic extracts (50, 70 and 100\%) of fresh and dry leaves of Melia azedarach on third and fourth instars of Aedes aegypti, after 48 hours of exposure. Temperature of $25 \pm 2{ }^{\circ} \mathrm{C}$ and $\mathrm{RH}$ of $75-85 \%$, with a light: dark ratio of $14: 10$. 
Table 1 - Lethal concentrations of hydroethanolic extracts (50, 70 and 100\%) of fresh leaves of Melia azedarach on third and fourth instars of Aedes aegypti, after 24 and 48 hours of exposure.

\begin{tabular}{|c|c|c|c|c|c|c|}
\hline $\begin{array}{l}\text { Extracts } \\
\text { (\% ethanol) }\end{array}$ & $\begin{array}{l}\text { Hours of } \\
\text { exposure }\end{array}$ & instars & $\begin{array}{c}\mathrm{LC}_{50}(\%) \\
(\mathrm{CI})\end{array}$ & Slope \pm SD & $X^{2}$ & $\overline{\mathrm{df}}$ \\
\hline \multirow[t]{8}{*}{ Fresh leaves (50\%) } & $24 \mathrm{~h}$ & & 1.25 & $2.98 \pm 0.32$ & 0.65 & 1 \\
\hline & & 3 & $(1.09-1.47)$ & & & \\
\hline & & & 1.30 & $2.12 \pm 0.29$ & 0.42 & 1 \\
\hline & & 4 & $(1.10-1.63)$ & & & \\
\hline & $48 \mathrm{~h}$ & & 0.64 & $4.39 \pm 0.39$ & 1.72 & 2 \\
\hline & & 3 & $(0.59-0.70)$ & & & \\
\hline & & & 0.89 & $2.67 \pm 0.29$ & 0.75 & 1 \\
\hline & & 4 & $(0.77-1.02)$ & & & \\
\hline \multirow[t]{8}{*}{ Fresh leaves (70\%) } & $24 \mathrm{~h}$ & & 0.57 & $2.34 \pm 0.27$ & 0.15 & 1 \\
\hline & & 3 & $(0.49-0.70)$ & & & \\
\hline & & & 1.32 & $2.14 \pm 0.22$ & 0.32 & 2 \\
\hline & & 4 & $(1.10-1.66)$ & & & \\
\hline & $48 \mathrm{~h}$ & & 0.29 & $2.67 \pm 0.28$ & 0.72 & 1 \\
\hline & & 3 & $(0.25-0.33)$ & & & \\
\hline & & & 0.33 & $3.07 \pm 0.29$ & 2.90 & 1 \\
\hline & & 4 & $(0.29-0.38)$ & & & \\
\hline \multirow[t]{8}{*}{ Fresh leaves $(100 \%)$} & $24 \mathrm{~h}$ & & 0.51 & $2.02 \pm 0.20$ & 2.08 & 1 \\
\hline & & 3 & $(0.42-0.62)$ & & & \\
\hline & & & 0.55 & $3.29 \pm 0.28$ & 0.48 & 1 \\
\hline & & 4 & $(0.47-0.64)$ & & & \\
\hline & $48 \mathrm{~h}$ & & 0.26 & $3.21 \pm 0.39$ & 1.69 & 1 \\
\hline & & 3 & $(0.23-0.30)$ & & & \\
\hline & & & 0.38 & $2.59 \pm 0.21$ & 4.34 & 2 \\
\hline & & 4 & $(0.33-0.43)$ & & & \\
\hline
\end{tabular}

$\mathrm{LC}_{50}$ : lethal concentration that causes $50 \%$ of mortality, SD: standard deviation, df: degrees of freedom, X2: chi-square, CI: confidence intervals..

Table 2 - Lethal concentrations of hydroethanolic extracts (50, 70 and 100\%) of dry leaves of Melia azedarach on third and fourth instars of Aedes aegypti, after 24 and 48 bours of exposure.

\begin{tabular}{|c|c|c|c|c|c|c|}
\hline $\begin{array}{l}\text { Extracts } \\
\text { (\% ethanol) }\end{array}$ & $\begin{array}{l}\text { Hours of } \\
\text { exposure }\end{array}$ & instars & $\begin{array}{c}\mathrm{LC}_{30}(\%) \\
(\mathrm{CI})\end{array}$ & Slope \pm SD & $X^{2}$ & $\mathrm{df}$ \\
\hline \multirow[t]{8}{*}{ Dry leaves $(50 \%)$} & $24 \mathrm{~h}$ & & 1.08 & $2.31 \pm 0.28$ & 1.10 & 2 \\
\hline & & 3 & $(0.94-1.27)$ & & & \\
\hline & & & 1.15 & $2.03 \pm 0.28$ & 2.71 & 1 \\
\hline & & 4 & $(0.96-1.42)$ & & & \\
\hline & $48 \mathrm{~h}$ & & 0.64 & $3.08 \pm 0.31$ & 4.79 & 2 \\
\hline & & 3 & $(0.57-0.71)$ & & & \\
\hline & & & 0.47 & $2.74 \pm 0.31$ & 0.49 & 2 \\
\hline & & 4 & $(0.40-0.54)$ & & & \\
\hline \multirow[t]{8}{*}{ Dry leaves $(70 \%)$} & $24 \mathrm{~h}$ & & 0.63 & $2.06 \pm 0.21$ & 2.61 & 2 \\
\hline & & 3 & $(0.54-0.74)$ & & & \\
\hline & & & 0.33 & $2.48 \pm 0.20$ & 0.56 & 3 \\
\hline & & 4 & $(0.28-0.37)$ & & & \\
\hline & $48 \mathrm{~h}$ & & 0.28 & $2.32 \pm 0.17$ & 2.80 & 3 \\
\hline & & 3 & $(0.25-0.32)$ & & & \\
\hline & & & 0.19 & $2.58 \pm 0.18$ & 1.18 & 3 \\
\hline & & 4 & $(0.17-0.22)$ & & & \\
\hline \multirow[t]{8}{*}{ Dry leaves (100\%) } & $24 \mathrm{~h}$ & & 0.37 & $3.31 \pm 0.26$ & 0.07 & 2 \\
\hline & & 3 & $(0.33-0.41)$ & & & \\
\hline & & & 0.33 & $2.45 \pm 0.18$ & 0.35 & 2 \\
\hline & & 4 & $(0.28-0.38)$ & & & \\
\hline & $48 \mathrm{~h}$ & & 0.17 & $3.01 \pm 0.22$ & 1.60 & 2 \\
\hline & & 3 & $(0.14-0.20)$ & & & \\
\hline & & & 0.20 & & & \\
\hline & & 4 & $(0.18-0.23)$ & $3.69 \pm 0.29$ & 0.37 & 2 \\
\hline
\end{tabular}

$\mathrm{LC}_{50}$ : lethal concentration that causes $50 \%$ of mortality, SD: standard deviation, df: degrees of freedom, X2: chi-square, CI: confidence intervals.. 


\section{DISCUSSION}

All of the ethanol extracts of Melia azedarach tested caused mortality among the larvae of Aedes aegypti to some extent. However, those with higher concentrations of fresh and dry leaf extracts produced greater mortality rates, especially with 48 hours of exposure. Similar results were also obtained by Rossi et a ${ }^{17}$, who tested ethanol extracts of dry leaves of Melia azedarach on Aedes albopictus at doses ranging from $0.015 \mathrm{~g} \%$ to $1.20 \mathrm{~g} \%$, and obtained mortality at all doses and among all the instar larvae tested.

Comparing the mortality caused by the extracts of fresh leaves and the extracts of dry leaves of Melia azedarach (both extracted in 50,70 and $100 \%$ ethanol), it could be seen that both the increased ethanol concentration and the extraction liquid promoted reductions in the lethal concentration. This could be best observed when comparing fresh and dry leaves in 100\% ethanol, thus indicating that the best results were obtained by using dry leaves on both third and fourth instars (Figure 1). This finding may be associated with the raised lipophilicity of limonoids such as azadirachtin, which makes them insoluble in water but highly soluble in solvents such as acetone and ethano ${ }^{18}$. This characteristic ensures that limonoids are efficiently extracted using solvents that are less polar than water is, and it could explain the greater effect of the ethanolic extracts. Under the conditions of the bioassays, the ethanol concentration was important for increasing the efficacy of the botanical extracts against the Aedes aegypti larvae.

Azadirachtin and other limonoids relating to Azadirachta indica exhibit feeding inhibitory and growth regulatory activities. These compounds are highly biodegradable and possess only weak toxicity to non-target organisms, while being nontoxic to humans and mammals in general and having low persistence of systemic action ${ }^{19}$. The leaves of Azadirachta indica have also been shown to possess insecticidal activity in a large number of insect species. According to Mittchel et $\mathrm{al}^{10}$, the insecticidal property of the leaves is due to the presence of limonoids such as azadirachtin. It is likely that the leaves of Melia azedarach also contain sufficient quantity of limonoids with insecticidal activity, for them to act synergistically. Therefore, if the active agents with primary responsibility for larval mortality of Aedes aegypti were limonoids, confirmation would only be obtained from more in-depth studies, using samples of these isolated compounds.

Leaves of Melia azedarach have been studied in agriculture to control pest insects ${ }^{122}$. The results obtained from this study indicate that these botanical extracts could also be used as an alternative resource for controlling Aedes aegypti.

\section{REFERENCES}

1. Abou-Fakhr Hammad EM, Zournajian H, Talhouk S. Efficacy of extracts of Melia azedarach L. callus, leaves and fruits against adults of the sweetpotato whitefly Bemisia tabaci (Homoptera: Aleyrodidae). Journal of Applied Entomology 125: 483-488, 2001.

2. Bounechada M, Doumandji SE, Laouer, H. Laboratory evaluation of Melia azedarach L. and Eucalyptus globulus Labill. extracts in order to control Ocneridia volxemi Bolivar (Orthoptera: Pamphaginae) hoppers. Communications in agricultural and applied biological sciences 69: 235-244, 2004.

3. Carvalho MS, Caldas ED, Degallier N, Vilarinhos PT, Souza LC, Yoshizawa MA, Knox MB, Oliveira C. Susceptibility of Aedes aegypti larvae to the insecticide temephos in the Federal District, Brazil. Revista de Saúde Pública 38: 623-629, 2004.

4. Defago M, Valladares G, Banchio E, Carpinella C, Palacios S. Insecticide and antifeedant activity of different plant parts of Melia azedarach on Xanthogaleruca luteola. Fitoterapia 77: 500-505, 2006.

5. Finney DJ. Probit analysis. Cambridge University Press, Cambridge, United Kingdom, 1971.

6. Lima JB, Da-Cunha PM, Da Silva RC, Galardo AK, Soares SS, Braga IA, Ramos RP, Valle D. Resistance of Aedes aegypti to organophosphates in several municipalities in the State of Rio de Janeiro and Espirito Santo, Brazil. The American Journal of Tropical Medicine and Hygiene 68: 329-333, 2003.

7. Marcoris ML, Andrighetti MT, Takuku L, Glasser CM, Garbeloto VC, Bracco JE. Resistance of Aedes aegypti from the state of São Paulo, Brazil, to organophosphates insecticides. Memórias do Instituto Oswaldo Cruz 98: 703-708, 2003.

8. Marcoris ML, Camargo MF, Silva IG, Takaku L, Andrighetti MT. Modificação da suscetibilidade de Aedes aegypti ao temephos. Revista de Patologia Tropical 24: 31-40, 1995.

9. Mendonça FA, Silva KF, Santos KK, Ribeiro Junior KA, Sant'Ana AE. Activities of some Brazilian plants against larvae of the mosquito Aedes aegypti. Fitoterapia 76: 629-636, 2005.

10. Mitchell MJ, Smith SL, Johnson S, Morgan ED. Effects of the neem tree compounds azadirachtin, salannin, nimbin, and 6-desacetylnimbin on ecdysone 20-monooxygenase activity. Archives of Insect Biochemistry and Physiology 35: 199-209, 1997.

11. Montella IR, Martins AJ, Viana-Medeiros PF, Lima JB, Braga IA, Valle D. Insecticide resistance mechanisms of brazilian Aedes aegypti populations from 2001 to 2004. The American Journal of Tropical Medicine and Hygiene 77:467-477, 2007.

12. Mulla MS, Su T. Activity and biological effects of neem products against arthropods of medical and veterinary importance. Journal of the American Mosquito Control Association 15: 33-52, 1999.

13. Nathan SS, Savitha G, George DK, Narmadha A, Suganya L, Chung PG. Efficacy of Melia azedarach L. extract on the malarial vector Anopheles stephensi Liston (Diptera: Culicidae). Bioresource Technology 97: 1316-1323, 2006.

14. Pinheiro VC, Tadei WP. Evaluation of the residual effect of temephos on Aedes aegypti (Diptera, Culicidae) larvae in artificial containers in Manaus, Amazonas State, Brazil. Cadernos de Saúde Pública 18: 1529-1536, 2002.

15. Prophiro JS, Rossi JCN, Kanis LA, Santos TGD, Silva OS. Estudo comparativo do efeito larvicida de extratos de frutos verdes e maduros de Melia azedarach L. (Sapindales: Meliaceae) em Aedes aegypti L. (Diptera: Culicidae). BioAssay 3:2, 2008 .

16. Roel AR. Utilização de plantas com propriedades inseticidas: uma contribuição para o desenvolvimento rural sustentável. Revista Internacional de Desenvolvimento Local 1: 43-50, 2001.

17. Rossi JCN, Prophiro JS, Mendes AM, Kanis LA, Silva OS. Efeito larvicida de extratos etanólicos de folhas secas e frutos maduros de Melia Azedarach (Meliaceae) sobre Aedes albopictus. Latin American Journal of Pharmacy 26: 737-740, 2007.

18. Roy A, Saraf S. Limonoids: overview of significant bioactive triterpenes distributed in plants kingdom. Biological \& Pharmaceutical Bulletin 29: 191-201, 2006.

19. Schaaf O, Jarvis AP, Van Der Esch SA, Giagnacovo G, Oldham NJ. Rapid and sensitive analysis of azadirachtin and related triterpenoids from Neem (Azadirachta indica) by high-performance liquid chromatographyatmospheric pressure chemical ionization mass spectrometry. Journal of Chromatography A 21: 89-97, 2000.

20. Silva OS, Prophiro JS, Rossi JCN, Kanis LA, Blazius RD, Romão PRT. Larvicidal effect of Carapa guianensis (Meliaceae) against Aedes aegypti (Diptera: Culicidae). Journal of the American Mosquito Control Association 22: 699-701, 2006.

21. Silva OS, Romão PRT, Blazius RD, Prophiro JS. The use of Carapa guianensis (Meliaceae) as larvicidal against Aedes albopictus (Diptera: Culicidae). Journal of the American Mosquito Control Association 20: 456-457, 2004. 
22. Souza AP, Vendramim JD. Atividade ovicida de extratos aquosos de meliáceas sobre a mosca branca Bemisia tabaci (Gennadius) biótipo B em tomateiro. Scientia Agricola 57: 403-406, 2000

23. Souza AP, Vendramim JD. Atividade inseticida de extratos aquosos de meliáceas sobre a mosca branca Bemisia tabaci (Genn.) biótipo B (Hemiptera: Aleyrodidae). Neotropical Entomology 30: 133-137, 2001
24. Valladares GR, Ferreyra D, Defago MT, Carpinella MC, Palacios S. Effects of Melia azedarach on Triatoma infestans. Fitoterapia 70: 421-424, 1999.

25. Wandscheer CB, Duque JEL, Navarro-Silva MA, Fukuyama Y, Wohlke JL, Adelmann J, Fontana JD. Larvicidal action of ethanolic extracts from fruit endocarps of Melia azedarach and Azadirachta indica against the dengue mosquito Aedes aegypti. Toxicon 44: 829-835, 2004. 